sons, and there was a certain marked difference. The second, third and fourth layers had round cells and pyramidal with two or at most three processes; no tripolar cells. In the round cells the nuclens was often eccentric, the part around degenerated, and a clear space round that. In answer to Dr. Hack Take's question, Dr. Beach said that he had found the grey matter atrophied, bat never hypertrophied.

Dr. Junlus MickLr read a paper entitled "Notes on a Case of Brain Injury."

Owing to the lateness of the hour, Dr. Sarage did not proceed with his "Notes on Cases of General Paralysis," which had been placed on the agenda. The proceedings terminated with a vote of thanks to Dr. Sarage, and the anthorities of the Bethlem Hospital for the use of the room.

\title{
ILLUSIONS OF THE SENSES.
}

At the Casnal Club, Isondon, Mr. Stuart Cumberland gave, on the 25th Nov.. some curious illustrations of the way in which the senses are liable to be imposed upon and mystified, especially when under the gaiding, or rather mis. gaiding, inflnence of expectant attention. The primary object of the exhibition was to expose modern spiritualism; but its interest for the psychologist consisted mainly in the confusion induced in the sensory perceptions by certain manifestations. Thus, for example, Mr. Cumberland placed himself at a table with two gentlemen, sitting one on either side of him, with whose hands he joined his, the gas being lighted. Having satisfied themselves that both $\mathbf{M r}$. Cumberland's hands were attached to theirs, the 5 , at his request, shut their eyes, and were asked whether they still felt his hands touching theirs. They answered affirmatively, without any hesitation, whereas Mr. Cumberland had dexterously removed one of his hands, and made the other do duty for both. Having obtained their full assent to this proposition, the operator, having one hand free, employed it as a "spirit hand" to tonch the heads of the gentle. men, placing also apon one a trombone. Mr. Cumberland then resamed his former connection by both hands, without the subjects of the experiment being conscions of the change; and when they opened their eyes they were clear in their opinion that whoever touched them and placed the instrument upon the head, Mr. Cumberland did not. The illusion was complete.

With other tricks resorted to by professional mediums we need not concern onrselves now; but we shall, we suppose, be expressing not only our own desire, but that of honest believers in spiritualism themselves, when wo say that we hope Mr. Cumberland will ruthlessly expose every opiritualistio impostor in Britain whom he can lay hands on.

If it be true, as he maintains, that he can produce every manifestation whioh cocurs in the presence of mediums, ander precisely the same conditions (no confederates, and submitting to the like examination of dress, so.), any one who wishes to investigate Spiritualism ought to ask Mr. Cumberland to aocompany him to the séance he attends.

\section{Obituary.}

WILLIAM LAUDER LINDSAY, M.D., F.R.S.E., F.L.S.

In our number for last January we noticed the retirement of Dr. Lander Lindsay, on account of the state of his health. Rest from his labour did not prolong his life, for he died in Edinburgh, on the 24th of November, at the age of 50. He was born in Edinburgh, and studied there as a boy at the High School, and as a stndent at the University, graduating as M.D. in 1862. Then, as ever after in his life, he was most industrious, carrying of prises and medals in nearly every class. Whatsoever he did he did with all his might, from the 
beginning of his life to the end. He was an omnivorons reader and a keen observer of nature, and was one of those earnest men who take life almost too seriously from the beginning. We believe it would have been well for him had he taken more relaxation and devoted more time to social intercourse. It seemed as if that would have sweetened and prolonged his life. But we know that a necessity is laid ou some natures to work, and never to rest. It is one form of the tyranny of their organisation. The power to relax all their energies, to put off their harness, to do nothing, to think of nothing, to feel nothing for a time, is not in them. For them variety of occupation is not rest, and they wenr themselves out before their tinue. The power to work hard is one of the most valuable of brain qualities no doubt, but it is less recognised that the power to do nothing needs to go with it to make a ronnded and perfect existence with long life and average happiness.

Dr. Lindsay, after taking his degree, had charge of the Cholera Hospital in Edinburgh, and studied that disease clinically, in face of the greatest personal risk. His observations were embodied in several valuable papers on the communicability of the disease to the lower animals, on its clinical aspects, and on its natural history. Eren as a student he showed himself to be an original botanist, selecting lichens as his favourite study. He afterwards published the " History of British Lichens," a very popular hand book. In the year 1853 he was appointed Assistant-Physician to the Crichton Royal Institution, Dumfries, then in the most flourishing period of its existence, under Dr. W. A. F. Browne's admirable management. In six months - far too short an spprenticeship to the complicated art of working successfully an asylum for all classes of society-he was, in 1854, appointed to the Physician-Superintendency of Murray's Royal Asylum, Perth, which he held for 25 years. From the moment he became the medical officer of an asylum he threw himself into the stady of insanity, and very valuable articles on the subject from his pen began to appear in the medical journals. It seemed indeed as if his pen was never idle. He studied and wrote on the dietetics of insanity, especially investigating the properties of glycerine as a fattening agent, on the pathology, therapentics, and hygiene of the subject, on the management of asylums, the superannuation of their officers, and the use of mechanical restraints in the treatment of the insane. He produced a new classification of insanity, and his annual Reports were exceedingly laborious and exhaustive. He also wrote articles on toxicology. But it was in the region of comparative psychology that he did the best work on the whole. For many years he observed the mental development of the lower animals, and gathered up all that appeared on the sabject in books, articles, and newspapers. No story of a dog's sagacity, or a parrot's loquacity that ever appeared in the most obscure corner of the most provincial newspaper, ever seems to have escaped him. In this and other journals he wrote most elaborate articles on this subject, and last year embodied the result of his life-long labours in his great work on "Mind in the Lower Animals in Health and Disease," a marvel of research, a mine of facts, and a wonder of arrangement and classification. He did not confine himself to professional matters, bat both thought and wrote on educational and social questions in the Edinburgh newspapers.

He was a man of slight physique, with the pinched featares of the chronic dyspeptio in later life. His temperament was highly nervous, sensitive, and a little irritable. His character was humane and honourable, and he always had the courage of his convictions. His habits were retiring, but industrious to a degree that shortened his life. Not a moment was wasted. He enjoyed a talk with a friend, but not general society. His amusement was travelling, and he had gone all over Europe from Norway nouthwards. He had visited America, Asis and New Zealand; and wandered, spud in hand, all over his native Scotch mountains. His temperament made him most jealous of any interference with his individual freedom of thought and actiou as an asylum physician. 'To official and statutory regulations and inspections he never took kindly, and was ever as ready to criticise the way in which Commissiouers and Directors did 
their work as they were to find fault with his. But to his patients he was always kind and forbearing, and his fellow officers loved and respected him. No institution in the kingdom of its size contained an older staff of officials. We think it was the sensitiveness of his temperament to control, and his not mingling much personally with his professional brethren that made him take up so fiercely a reactionary attitude towards the non-restraint movement. It was certainly not any want of benevolent feeling towards the insane. But he hated to be coerced by even a right pablic opinion into doing anything. One would have thought from some of his writings that he kept many of his patients in crib beds and strait jackets. In reality be used such things very sparingly. But if he thought one case in a million was the better for them he stoutly vindicated his intellectual freedom by proclaiming to all the world that such restraints were needed in some cases, and that therefore he would and did use them. The best of us have a hobby, and Dr. Lindsay's was to run a muck at the non-restraint principle, which he nick-named "Conollyism." He was so logical that he could not see that a few exceptions prove the rule. But the best proof that his views on this matter were recognised by his friends as being the hobby of an otherwise sound and progressive alienist, was the fact that they were allowed to pass with out notice or reply. They were, we need hardly say, totally opposed to the opinions and sentiments of the great body of British alienists.

It is sad to think that Dr. Lindsay enjoyed his life and his pension so little after his retirement. He bore the burden and heat of the day, and had no calm evening of rest and reward. The cares and worry of asylum life, and the strain of continned personal intercourse with the insane, wore him out before his time. It is doubtful if such sensitive temperaments as his should take to such a life at all. But he did his work nobly up to the last. Every officer in every asylum in the kingdom owes him a debt of gratitude for his work on "The Superannuation of Officers in British Hospitals for the Insane," in which with enormons labour and no little expense to himself, he set forth the facts and the argaments for pensions to old officers.

Few men in our profession have contributed to so many journals. That his scientific work was appreciated by the most competent authorities is best proved by the number of honours he received. He received a gold medai for his Thesis from his University, the Neill prize of the Royal Society of Edinburgh, and a medal from the Royal Society, besides medals from the International Exhibition of Fine Arts, and from the New Zealand Exhibition of 1865.

\section{DR. E. SEGUIN.}

By the death of Edward Seguin, M.D., of New York, medicine has lost one of its brightest ornaments, while those who are interested in the study of Idiocy and the education and training of Idiots and Imbeciles have sustained an irreparable loss. He was, so to speak, the pioneer in this great work, pointing out the landmarks to be observed and the means to be adopted in carrying it on. His attention was first called to the subject by Itard, who prevailed upon him to nndertake the education of the famous wild boy of Aveyron. As a result of his efforts, public attention was called to the subject. and in 1842 a portion of the Bicêtre was set apart for the instruction of idiots, and Dr. Segain was appointed director. Here he remained for some time, but subsequently established a private institution for idiots in Paris. During this time he prepared his treatise on the "Traitement moral, hygiéne et Education des idiots," a work of much merit. In consequence of the Revolution in France of 1848, Dr. Seguin went to America, and was soon appointed Superintendent of the Pennsylvania School for Idiots. After a while he resigned this appointment, and commenced practice as a consulting physician in New York. He then brought out a book, entitled "Idiocy, its 